\title{
Methods for glomerular quantification in dogs: a comparative study
}

\section{Caio Augusto Leles Costa $^{1^{*}}$ (D) Charles Silva de Lima ${ }^{1}$ Ricardo Andres Ramirez Uscategui ${ }^{2}$ Gyl Eanes Barros Silva ${ }^{3}$ Leandro Zuccolotto Crivellenti ${ }^{1}$}

'Programa de Pós-graduação em Ciência Animal, Hospital Veterinário, Universidade de Franca (UNIFRAN), 14404600, Franca, SP, Brasil. E-mail: drcaio@clinicacentervet.com. "Corresponding author.

${ }^{2}$ Departamento de Clínica e Cirurgia Veterinária, Universidade de São Paulo (UNESP), Jaboticabal, SP, Brasil.

${ }^{3}$ Departamento de Patologia Renal, Faculdade de Medicina de Ribeirão Preto, Universidade de São Paulo (USP), São Paulo, SP, Brasil.

ABSTRACT: It was evaluated the different methodologies for glomerular enumeration described in the literature in a quantitative, doubleblind study on the number of glomeruli present in kidney biopsy specimens obtained using a Tru-cut-type biopsy needle. Eighteen samples were taken ( $n=18)$ from various regions of canine kidneys harvested immediately after euthanasia. Sample collection was carried out using Tru-cut-type, semi-automated, 16 gauge needles. Reading and evaluation of the specimens were performed independently by four researchers by means of eye loupe inspection, light microscopy, light microscopy with a reduced condenser aperture, and dissection microscopy. Samples were also subjected to histopathological evaluation for comparison purposes. There was no inter-researcher variation for any of the tested methods. The glomerular counts obtained using light microscopy with reduced condenser aperture were similar to those reported in the histopathological evaluation $(P=0.44)$; whereas, the other glomerular enumeration methods yielded significantly lower counts when compared to the histopathological analysis (eye loupe inspection: $P<0.01$; conventional light microscopy: $P=0.02$; dissection microscopy: $P<0.01$ ). Light microscope with lowering of the condenser lens delivers better results than conventional light microscopy and eye loupe inspection. Results obtained using dissection microscopy and eye loupe inspection did not correlate well with those provided by histopathological evaluation; consequently, these two methods should be avoided.

Key words: glomerulopathy, histopathology, light microscopy.

Metodologias para quantificação glomerular em cães: um estudo comparativo

RESUMO: Avaliou-se as diferentes metodologias de quantificação glomerular descritas na literatura em um estudo quantitativo, duplocego, sobre o número de glomérulos presentes em amostras de biópsias renais obtidas com agulha de biópsia tipo Tru-cut. Dezoito amostras foram coletadas $(n=18)$ de várias regiões de rins caninos colhidos imediatamente após a eutanásia. A coleta das amostras foi realizada com agulhas semi-automáticas de calibre 16, tipo Tru-cut. A leitura e avaliação das amostras foram realizadas de forma independente por quatro pesquisadores por meio de inspeção visual, microscopia de luz, microscopia de luz com redução da lente condensadora e microscopia de dissecção. As amostras também foram submetidas à avaliação histopatológica para fins de comparação e variação do pesquisador para qualquer um dos métodos testados. As contagens glomerulares obtidas por microscopia de luz com redução da lente condensadora foram semelhantes àquelas encontradas na avaliação histopatológica $(P=0.44)$, enquanto que os outros métodos de quantificação glomerular produziram contagens significativamente mais baixas a análise histopatológica (inspeção da lupa dos olhos: $P<0.01$; microscopia de luz convencional: $P=0.02$; microscopia dissecação: $P<0.01$ ). Microscópio de luz com abaixamento da lente condensadora fornece melhores resultados do que microscopia de luz convencional e inspeção da lupa. As contagens obtidas usando microscopia de dissecção e inspeção de lupa de olho não se correlacionaram bem com aqueles fornecidos pela avaliação histopatológica; consequentemente, estes dois métodos devem ser evitados.

Palavras-chave: glomerulopatias, histopatologia, microscópio de luz.

\section{INTRODUCTION}

Renal biopsy is as an important tool to determine the cause of the disease in patients with chronic kidney disease; additionally, it helps determine prognosis and choose the most appropriate treatment protocol. Therefore, histological examination of kidney tissue obtained by biopsy is considered to be the gold standard for the definitive diagnosis of kidney diseases (VADEN et al., 2005; KARAM et al., 2010; LEES et al., 2011).

Proper assessment of canine kidney biopsy specimens with glomerular diseases is believed to require about 2 to 3 samples of renal tissue to allow a precise histological evaluation (HUSSAIN et al., 2010; CIANCIOLO et al., 2013).

Renal tissue should be fragmented, and a minimum of 10 glomeruli are needed to evaluate the 
sample using light microscopy (CRIVELLENTI et al., 2018). Additional tissue fragments are required to carry out electron and immunofluorescence microscopy analyses to enable a definitive diagnosis (CIANCIOLO et al., 2013).

However, before histopathological evaluation fresh samples should be analyzed to confirm the presence of glomeruli (WALKER 2009; LEES et al. 2011). There are several methods to estimate the quality and number of glomeruli. These methods include loupe (10X) inspection, dissection microscopy (WALKER 2009; LEES et al. 2011), and conventional light microscopy (VADEN 2004; VADEN et al., 2005; LEES et al., 2011).

However, to date, there are no studies indicating the best method to estimate the number of glomeruli in kidney biopsy specimens. Therefore, this study aimed to compare the different glomerular number estimation methods described in the literature, and establish the best technique is the most effective for the visualization and enumeration of glomeruli in kidney biopsy samples.

\section{MATERIALS AND METHODS}

Eighteen uniform kidney samples were obtained from 6 fresh kidneys collected immediately after euthanasia. Sample collection was performed by a veterinary nephrologist with direct renal visualization. Semi-automated, 16 gauge Tru-cuttype needles (M.D.L. ${ }^{\circledR}$ Aghi specialli e componenti medicalli, Italy) were used for all biopsies. Samples were collected randomly as follows: six samples were collected from the renal cortex, six samples were obtained from the cortex-medullary transition, and six other samples were collected from the renal medulla; these latter samples were used as negative controls. The tissue fragments were carefully removed from the biopsy needle with a scalpel blade, and hydrated with saline solution. The samples were then mounted on standard glass slides for evaluation.

A veterinary nephrologist collected kidney samples in order to ensure a blind glomerular count. The samples were collected by a single professional, and remained unidentified while the count was performed by four other veterinarians. Therefore, each tissue fragment was randomly collected by the nephrologist and blindly provided to the other veterinarians to quantify the number of glomeruli in each sample using the methods listed below. None of the veterinarians who received these samples had prior experience with glomerular counting methods.
The following methods were used to estimate the number of glomeruli in the tissue fragments: 1) inspection with an eye loupe; 2) conventional light microscopy; 3) light microscopy with a small condenser aperture; and 4) stereo microscopy. The first method consisted of direct observation of the kidney biopsy fragments using a regular eye loupe without a light source. In the second method, the veterinarian evaluated renal biopsy fragments with a light microscope (at a 10X magnification). In the third method, the renal biopsy sample was assessed using a light microscope with lowering of the condenser lens; this reduced aperture was attained by decreasing the aperture of the iris diaphragm located between the condenser lens and the stage of the microscope. In the fourth method, the tissue fragments were evaluated using a dissecting microscope with a light source at a 10X magnification.

In order to establish a final benchmark, samples were fixed for 24 hours in $10 \%$ buffered formalin after analysis by the different glomerular enumeration methods, and were then processed using standard procedures for dehydration and paraffin embedding at the Veterinary Pathology Service. Sections were cut at 2-3 $\mu \mathrm{m}$ thickness, stained with Masson's trichrome, and analyzed using an optical microscope to determine the number of glomeruli of samples. This procedure, termed "histopathological evaluation" herein, was regarded the "gold standard" for determination of renal glomeruli numbers in each sample. This procedure was performed by two pathologists and all area sample was evaluated in $10 \mathrm{X}$ and $40 \mathrm{X}$ magnification. At the end of the process, all the data were properly identified and comparatively analyzed.

Statistical analysis was performed using $\mathrm{R}^{\circledR}$ software (R Foundation for Statistical Computing; Vienna, Austria). Initially, inter-researcher variation was analyzed with the Kruskal-Wallis test. Next, the Wilcoxon signed-rank test was used to compare the number of glomeruli reported in fresh samples using each glomerular enumeration method with the number of glomeruli reported using the histopathological evaluation, medulla was categorized in presence or absence. Finally, the correlation between the number of glomeruli obtained using each method and the histopathological evaluation was assessed by means of the Spearman test.

\section{RESULTS}

All the glomerular enumeration methods used in this study were able to deliver estimations of 
glomerular numbers in fresh renal biopsy samples. No inter-researcher differences were observed for any of the tested methods (eye loupe inspection, $\mathrm{P}=0.91$; conventional microscopy, $\mathrm{P}=0.29$; light microscope with lowering of the condenser lens, $\mathrm{P}=0.14$; dissecting microscopy, $\mathrm{P}=0.58$ ).

Light microscope with lowering of the condenser lens was the only method that yielded glomerular counts similar to those reported during histopathological evaluation $(\mathrm{P}=0.44)$ (Figure 1$)$. In contrast, the other glomerular enumeration methods yielded significantly lower counts when compared with histopathologic evaluation (eye loupe inspection: $\mathrm{P}<0.01$; conventional microscopy $\mathrm{P}=0.02$; dissecting microscopy: $\mathrm{P}<0.01$ ) (Table 1).

The number of glomeruli assessed using these different methods and the median \pm IQR (interquartile range) for each group are shown in figure 2. In considering the correlation between glomerular counts yielded by the different glomerular enumeration methods used in this study, light microscope with lowering of the condenser lens showed the highest correlation with the histopathological evaluation $(\mathrm{r}=0.63 ; \mathrm{P}<0.01)$, followed by conventional microscopy $(\mathrm{r}=0.46$, $\mathrm{P}<0.01)$. Dissecting microscopy $(\mathrm{r}=0.23 ; \mathrm{P}=0.07)$ and eye loupe inspection $(\mathrm{r}=-0.18 ; \mathrm{P}=0.16)$ did not correlate with the histopathological evaluation.

\section{DISCUSSION}

Despite the small number of samples and individuals included in this study, it should be stressed that even though the professionals involved in this work had prior knowledge on histopathology, but they had no experience with methods of glomeruli number estimation. This may reflect the reality of veterinary clinics and hospitals where renal biopsies are performed only occasionally.

Although, several methods are available to estimate glomerular numbers, most studies in the literature reveal a preference for the use of light microscopy (VADEN, 2005), eye loupe inspection (CIANCIOLO et al., 2013, LEES, 2011), and dissecting microscopy (WALKER, 2009), which indicates that some methods are more difficult for beginners and exhibit low reproducibility, as noted during glomerular enumeration using eye loupe inspection and dissecting microscopy. Even though only kidneys with no histological alterations were used in this research, the conclusions of this study probably also are applied to cases in which glomerular disorders are present.

LEES (2011) reported that the initial evaluation of renal tissue samples can be performed with a dissecting microscope at low magnifications (10X to $40 \mathrm{X})$ and also reported that the use of a

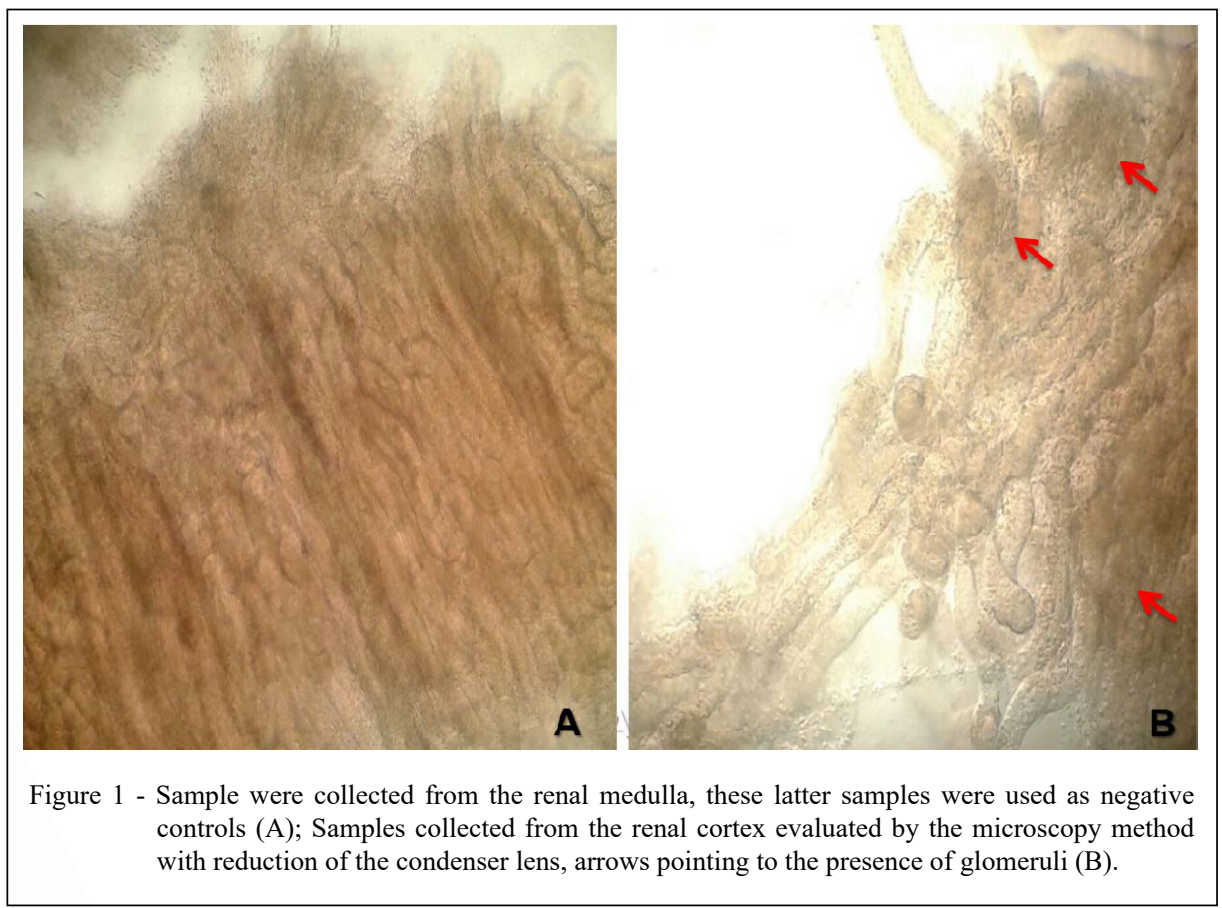

Ciência Rural, v.49, n.3, 2019. 
Table 1 - Number of glomeruli (mean \pm std deviation) in eye loupe inspection (EL), conventional light microscopy (ML), light microscopy with reduced condenser aperture (MC), stereo microscopy (SM) comparing with histopathological evaluation (HE).

\begin{tabular}{lcr}
\hline & Number of glomeruli & $P$ Value \\
\hline EL & $0.8 \pm 1.7$ & $<0.01$ \\
ML & $2.0 \pm 3.6$ & 0.02 \\
MC & $3.1 \pm 4.8$ & 0.44 \\
SM & $0.5 \pm 1.5$ & $<0.01$ \\
HE & $3.7 \pm 5.4$ & - \\
\hline
\end{tabular}

magnifying glass or even an eye loupe (or hand lens) may constitute a method to evaluate a kidney biopsy sample. VADEN (2005) and CIANCIOLO et al. (2013) described conventional light microscopy as a technique that allows initial evaluation of glomeruli numbers in fresh renal tissue.

However, contrary to the findings described in the present research, most previous studies have not comparatively evaluated the efficacy of distinct methods used for glomerular quantification. Our study showed that, in considering glomerular counts, light microscope with lowering of the condenser lens was more effective than eye loupe inspection, conventional microscopy, and dissecting microscopy. Surprisingly, the number of glomeruli revealed by light microscope with lowering of the

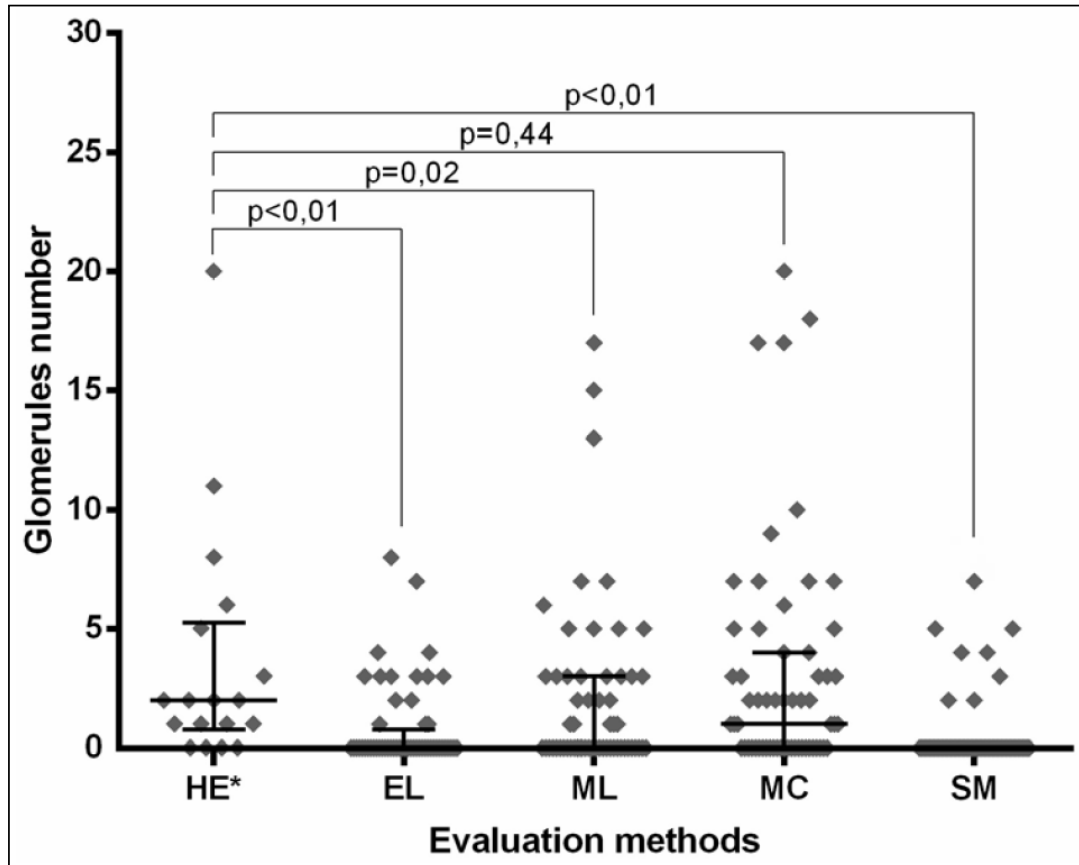

Figure 2 - Distribution of glomeruli numbers in kidney biopsy samples as assessed by different methods, and median \pm IQR (interquartile range) for each method.

Caption.

HE*: Histopathological evaluation EL: Eye loupe inspection ML: conventional light microscopy MC: light microscopy with reduced condenser aperture.

SM: stereo microscopy. $\mathrm{P}<0.01$.

Ciência Rural, v.49, n.3, 2019. 
condenser lens exhibited the best correlation with those reported using histopathological evaluation despite the fact that the use of this microscopy technique has not been previously reported for the purpose of glomerular quantification. The initial idea of using this method came from a study that evaluated dysmorphic erythrocytes in the urine of patients with glomerulopathies, in which this method delivered better results than conventional light microscopy (SILVA, 2010).

Although, the methods described in this study are not described in the literature, it is noteworthy that their cost is low. Therefore, no high investments are required to perform these techniques. Consequently, light microscope with lowering of the condenser lens is an easy-to-use technique with low operating costs that may be used as an auxiliary tool to count glomeruli in fresh kidney samples. This would allow a better selection of kidney tissue samples to be subjected to histopathological evaluation.

Histopathological evaluation is still the gold standard for the diagnosis of renal diseases. However, appropriate sample choice depends on initial tissue assessment in fresh kidney samples using standard techniques.

\section{CONCLUSION}

Evaluation of fresh renal tissue by conventional light microscope with lowering of the condenser lens is an efficient and easy method to implement. Therefore, this method could be a useful auxiliary tool for assessing glomerular numbers in renal biopsy samples.

\section{ACKNOWLEDGEMENTS}

The authors would like to thank Fundação de Amparo à Pesquisa do Estado de São Paulo (FAPESP process \#2014/215062) for financial support, Conselho Nacional de Desenvolvimento Científico e Tecnológico $(\mathrm{CNPq})$ for support the Animal Science Graduate Program.

\section{BIOETHICS \\ COMMITTEE \\ BIOSSECURITY}

This study was approved by the Ethics Committee on Animal Use (CEUA) of the University of Franca (UNIFRAN), SP under protocol no. 6241060416.

\section{DECLARATION OF CONFLICT OF INTERESTS}

The authors declare no conflict of interest. The founding sponsors had no role in the design of the study; in the collection, analyses, or interpretation of data; in the writing of the manuscript, and in the decision to publish the results.

\section{AUTHORS' CONTRIBUTIONS}

The authors contributed equally to the manuscript.

\section{REFERENCES}

CIANCIOLO, R.E. et al. Pathologic evaluation of canine renal biopsies: methods for identifying features that differentiate immune-mediated glomerulo nephritides from other categories of glomerular diseases. Journal of Veterinary Internal Medicine, n.27, p.10-18, 2013. Available from: <https://www.ncbi.nlm.nih. gov/pubmed/24635375>. Accessed: Nov. 20, 2016. doi: 10.1111/ jvim. 12226.

CRIVELLENTI, L.Z. et al. Associations of patient characteristics, disease stage, and biopsy technique with the diagnostic quality of core needle renal biopsy specimens from dogs with suspected kidney disease. Journal of the American Veterinary Medical Association, v.252, n.1, p.6774, 2018. Available from: <https://www.ncbi.nlm.nih.gov/ pubmed/29244598>. Accessed: May, 07, 2018. doi: 10.2460/ javma.252.1.67.

HUSSAIN, F. et al. Renal biopsies in children: current practice and audit of outcomes. Nephrology Dialisis Transplantation, n.25, p.485-489, 2010. Available from: <https://academic.oup. com/ndt/article/25/2/485/1815346>. Accessed: Nov. 05, 2016. doi: $10.1093 / \mathrm{ndt} / \mathrm{gfp} 434$.

KARAM, A.R. et al. Curved stylet core biopsy results in larger cores. American Journal Roentgenology, v.195, n.1, p.242244, 2010. Available from: <https://www.ncbi.nlm.nih.gov/ pubmed/20566823>. Accessed: Nov. 20, 2016. doi: 10.2214/ AJR.09.3472

LEES, G.E.; et al.,. Renal biopsy and pathologic evaluation of glomerular disease. Topics in companion animal medicine, v.26, p.143-153, 2011. Available from: <https://www.ncbi.nlm.nih.gov/ pubmed/24635375>. Accessed: Nov. 20, 2016. doi: 10.1053/j. tcam.2011.04.006.

LEES, G.E. Early diagnosis of renal disease and renal failure. Veterinary Clinics of North America: Small Animal Practice, p.867-885, 2004. Available from: <https://www.ncbi.nlm.nih.gov/ pubmed/15223206>. Accessed: Sep. 18, 2016. doi: 10.1016/j. cvsm.2004.03.004.

SILVA, G.E.B. et al. Evaluation of erythrocyte dysmorphism by light microscopy with lowering of the condenser lens: A simple and efficient method. Nephrology, v.15, p.171-177, 2010. Available from: <https://onlinelibrary.wiley.com/doi/pdf/10.11 11/j.1440-1797.2009.01197.x>. Accessed: Sep. 09, 2016. doi: 10.1111/j.1440-1797.2009.01197.x.

VADEN, S.L. Renal biopsy: methods and interpretation. Veterinary Clinics of North America: Small Animal Practice, v.34, n.4, p.887-980, 2004. Available from: <https://www.ncbi. nlm.nih.gov/pubmed/15223207>. Accessed: Sep. 11, 2016. doi: 10.1016/j.cvsm.2004.03.010.

VADEN, S.L. Renal biopsy of dogs and cats. Clinical Techniques in Small Animal Practice, v.20, n.1, p.11-22, 2005. Available from: 
$<$ https://www.ncbi.nlm.nih.gov/pubmed/15822526>. Accessed: Sep. 15, 2016. doi: 10.1053/j.ctsap.2004.12.003.

VADEN, S.L. et al. Renal biopsy: a retrospective Study of Methods and Complications in 283 Dogs and 65 Cats. Journal Veterinary Internal Medicine, v.19, p.794-801, 2005. Available from: $<$ https:// www.ncbi.nlm.nih.gov/pubmed/16355671>. Accessed: Sep. 16,
2016. doi: http://dx.doi.org/10.1892/0891-6640(2005)19[794:RBA $\mathrm{RSO}] 2.0 . \mathrm{CO} ; 2$.

WALKER, P.D. The renal biopsy. Archiches of Pathology and Laboratory Medicine, v.133, p.181-188, 2009. Available from: $<$ https://www.ncbi.nlm.nih.gov/pubmed/19195962>. Accessed: Oct. 19, 2016. doi: 10.1043/1543-2165-133.2.181. 